\title{
Relative condition factor and food and feeding of Jones' pony fish Eubleekeria jonesi (James, 1971) from Mandapam waters, Tamil Nadu, India
}

\author{
L. REMYA ${ }^{1}$, P. U. ZACHARIA², S. P. SHUKLA ${ }^{3}$, MOLLY VARGHESE ${ }^{2}$, A. K. JAISWAR ${ }^{3}$ \\ AND A. K. ABDUL NAZAR ${ }^{4}$ \\ ${ }^{1}$ Mandapam Regional Centre of ICAR-Central Marine Fisheries Research Institute, Mandapam - 623520 \\ Tamil Nadu, India \\ ${ }^{2}$ ICAR-Central Marine Fisheries Research Institute, Kochi - 682 018, Kerala, India \\ ${ }^{3}$ ICAR-Central Institute of Fisheries Education, Versova - 400 061, Maharashtra, India \\ ${ }^{4}$ Madras Research Centre of ICAR-Central Marine Fisheries Research Institute, Chennai - 600 028, Tamil Nadu, India \\ e-mail:lremya9@gmail.com
}

\begin{abstract}
The relative condition factor $(\mathrm{Kn})$ based on length-weight relationship and food and feeding habits of Jones' pony fish Eubleekeria jonesi (James, 1971) off Mandapam waters was studied during December 2016 - April 2018. The Kn values showed variations on a monthly basis with maximum value during September (1.23) for male and March (1.53) for female. Analysis of fullness of stomach of 961 samples within the size range of 51-130 mm revealed $40.87 \%$ fishes as actively fed, $36.19 \%$ as moderately fed and remaining $22.94 \%$ as poorly fed. The monthly mean fullness index (FI) was highest during September for both sexes. Highest gonadosomatic index (GSI), vacuity index (VI) and Kn value were observed during March-April in females, probably indicating a spawning peak and hence meagre feeding, which resulted in lowest fullness index (FI). Fishes of smallest length group (51-70 mm) had highest FI and minimum VI and vice versa. The values of index of relative importance (IRI) indicated that the species was planktivorous as well as detritivorous, with top priority towards crustaceans $(27.6 \%)$ followed by bivalves $(23.6 \%)$, foraminifera $(15.4 \%)$, phytoplankton $(12.5 \%)$, gastropods $(9.1 \%)$ and nematodes $(8.3 \%)$ in the gut contents. Diet did not show significant variation either sex-wise or size-wise.
\end{abstract}

Keywords: Eubleekeria jonesi, Feeding intensity, Food and feeding, Index of relative importance, Mandapam, Relative condition factor

\section{Introduction}

Leiognathids (Family:Leiognathidae), commonly known as silverbellies, slipmouths, ponyfishes or slimys, are small fishes widely distributed in the Indo-Pacific and the Western Central Atlantic Oceans. They occupy shallow-coastal waters up to $40 \mathrm{~m}$ depth and sometimes enter estuaries (James and Badrudeen, 1975). The annual landing of ponyfishes in India in 2017 was 89901 t, which registered $7.09 \%$ decrease from 2016 . The highest contribution of $85.24 \%$, during the period came from Tamil Nadu on the south-east coast of India (CMFRI, 2018). Ponyfishes occupy an efficient ecological niche and are typically characterised by the upward, horizontal or downward extensions of mouth, which enable them to avoid inter- and intra- specific competition for food.

Length-weight relationship (LWR) for a given species gives the best estimates of growth status at a particular point of time (von Bertalanffy, 1938). The value of relative condition factor, $\mathrm{Kn}$ is calculated from the LWR and can be used to estimate changes in nutritional condition and well-being of the fish during the course of time (Jin et al., 2015). Diet and feeding strategies play a key role in the trophodynamics of fishes to determine the extent of growth, fecundity, migratory movements and biological interactions in an ecosystem.

Several studies on the food and feeding behaviour of silverbellies along the Indian coast have been carried out viz., on Leiognathus bindus off Calicut (Balan, 1967) and Ratnagiri coast (Borah et al., 2016), L. brevirostris off Palk Bay (James and Badrudeen, 1975) and off Kerala (Sebastian and Inasu, 2011), L. dussumieri off Mandapam waters (James and Badrudeen, 1981) and off Tuticorin (Nagarajan, 2014), L. jonesi from Palk Bay and Gulf of Mannar (James, 1986) and L. splendens off Ratnagiri coast (Acharya and Naik, 2016). The present study was carried out to assess the condition factor, diet and feeding habits of Eubleekeria jonesi (James, 1971) from Mandapam waters and to update the earlier observations made more than three decades ago by James (1986). 


\section{Materials and methods}

Fish samples were collected fortnightly from trawl landings at Rameswaram and Mandapam fish landing centres (FLC), Tamil Nadu during December 2016-April 2018. Out of 961 samples, 629 were collected from Rameswaram and remaining 332 from Mandapam FLC. Total length (TL) of the fish was taken as the distance between tip of the snout and tip of the upper caudal lobe and was measured in mm using a graduated measuring scale. Total body weight and stomach weight of the fish were recorded to an accuracy of $0.01 \mathrm{~g}$ using an electronic balance.

Length-weight relationship was derived using the exponential hypothetical formula $\mathrm{W}=\mathrm{aL}^{\mathrm{b}}$ given by Le Cren (1951). This relationship was linearised by logarithmic transformation to get the equation, $\log \mathrm{W}=\log \mathrm{a}+\mathrm{b} \log \mathrm{L}$, where the constants ' $a$ ' and ' $b$ ' were derived by linear least squares method. The equations were derived separately for males and females for comparison using Analysis of Covariance (ANACOVA) (Snedecor and Cochran, 1967). The relative condition factor, Kn (Le Cren, 1951) was computed as the ratio of observed weight to estimated weight for each fish as per the equation:

$$
\mathrm{Kn}=\frac{\mathrm{W}}{\mathrm{aL^{ \textrm {b } }}}
$$

where, ' $\mathrm{W}$ ' and ' $\mathrm{L}$ ' are weight and length of the individual fish respectively, ' $a$ ' and 'b' are constants derived from LWR.

The stomach contents of 961 specimens of $E$. jonesi ranging in size from 60 to $126 \mathrm{~mm}$ and in weight from 3.36 to $42.24 \mathrm{~g}$ were examined. For each specimen, the total length, sex, maturity stage and weight were noted in fresh condition. Gut was removed and preserved in 5\% buffered formalin for further studies. The stomach contents were analysed and index of relative importance (IRI\%) was computed following Pinkas et al. (1971) through suitable modification to estimate volume index:

$$
\mathrm{IRI}=(\% \mathrm{~N}+\% \mathrm{~V}) \% \mathrm{O}
$$

where, $\% \mathrm{~N}, \% \mathrm{~V}$ and $\% \mathrm{O}$ represent percentages of number, volume and frequency of occurrence of prey.

The identified groups in the stomach contents were allotted points according to their volume in the stomachs. In this way one large organism counted as much as several small ones. These points were multiplied with the number counted. All the products were added up and converted into percentages (volume) for all items in different months (Hynes, 1950).

The intensity of feeding in each fish was determined by eye examination based on the distension of the stomach and the amount of food contained in the stomach. The various stomach conditions were gorged, full, $3 / 4$ full, $1 / 2$ full, $1 / 4$ full and empty in which gorged and full were considered as indication of 'actively fed', $3 / 4$ full and $1 / 2$ full as indication of 'moderately fed' and the rest of the conditions i.e., $1 / 4$ full and empty as 'poorly fed' (Jayabalan and Ramamoorthi, 1985; Sebastian and Inasu, 2011; Nagarajan, 2014). The gut contents of each fish was emptied into a petridish and examined under binocular microscope (Nikon SMZ1270) at 8x magnification and identified up to generic level in the case of zooplankton and benthos and upto species level for phytoplankton. If the food items were in an advanced state of digestion, they were labelled as 'semi-digested matter'.

Monthly as well as size-wise feeding intensity was also assessed using the vacuity index, VI (Preciado et al., 2014) and fullness index, FI (Hyslop, 1980). VI is the proportion of empty stomachs, estimated as :VI $=\frac{\mathrm{Nes}}{\mathrm{Ts}} \times 100$, where Nes is the number of empty stomachs and $T \mathrm{~s}$ is the total number of stomachs. Fullness index (FI) is the ratio of weight of stomach content to weight of fish, multiplied by 100 .

Monthly feeding intensity in relation to spawning activity was compared with gonadosomatic index (GSI) using the formula (Strum, 1978):

$$
\text { GSI }=\frac{\text { Weight of ovary }}{\text { Weight of fish }} \times 100
$$

\section{Results and discussion}

\section{Length-weight relationship}

A common LWR, W=0.0177x $\mathrm{L}^{3.0105}\left(\mathrm{r}^{2}=0.9484\right)$, was derived for male and female $E$. jonesi as ANACOVA revealed no significant difference in the regression coefficients of the sexes (Table 1). It can be inferred that the pattern of growth in the two sexes are similar, isometric $(b \geq 3$ ) and follows the cube law (Fig. 1), with a high degree of positive correlation between length and weight of $E$. jonesi as indicated by the correlation co-efficient $\left(\mathrm{r}^{2}\right)$.

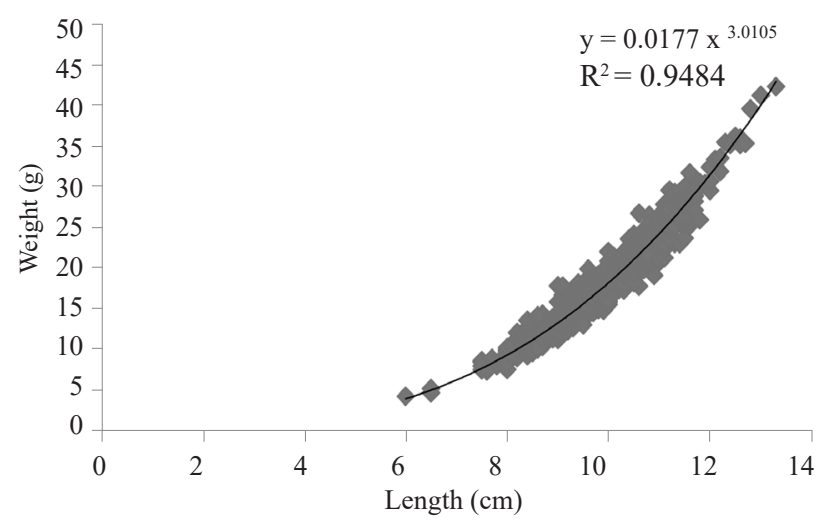

Fig. 1. Length-weight relationship of E. jonesi (sexes pooled). 
Table 1. Comparison of regression lines of male and female E. jonesi by ANACOVA

\begin{tabular}{llllllllll}
\hline Source & DF & SS-X & SP & SS-Y & b & DF & SS & MS & F \\
\hline Male & 279 & 225.61 & 1064.6 & 5431.5 & 4.72 & 278 & 407.89 & 1.47 & \\
Female & 528 & 526.76 & 2891.08 & 17093.17 & 5.49 & 527 & 1225.56 & 2.33 & \\
Total & & & & & & 805 & 1633.44 & 2.03 & \\
$\begin{array}{l}\text { Pooled (W) } \\
\text { Difference between slops }\end{array}$ & 807 & 752.36 & 3955.68 & 22524.67 & 5.26 & 806 & 1727.02 & 2.14 & \\
Between (B) & & & & & & 1 & 93.57 & 93.57 & 46.11507 \\
W + B & 1 & 70.06 & 441.4 & 2781 & & & & & \\
Difference between corrected means & 808 & 822.42 & 4397.08 & 25305.67 & 5.35 & 807 & 1796.7 & 2.23 & \\
\hline
\end{tabular}

Length-weight relationships of silverbellies in the Indian sub-continent have been studied by several authors. James and Badrudeen (1981) reported the $b$ values of male and female L. dussumieri from the Gulf of Mannar as 2.9591 and 3.3976 respectively. Karthikeyan et al. (1989) have reported the value of $b$ to be 2.87 for $L$. jonesi from Palk Bay and Batcha and Badrudeen (1992) reported it to be 3.004 for L. brevirostris from the same ground. The regression coefficient, $b$ of L. bindus (3.0515), $S$. insidiator (2.905) and G. minuta (2.9228) has been recorded from Chennai coast by Kizhakudan and Reddy (2012). Puvaneswari and Karuppasamy (2019) reported the $b$ value of $G$. minuta from Tuticorin as 2.95 and 3.07 for male and female respectively. The values of $b$ obtained for $E$. jonesi in the present study also fall in the same range.

\section{Relative condition factor}

The relative condition factor, $\mathrm{Kn}$ computed for male and female $E$. jonesi in each month during 2017 are presented in Fig. 2. The value of $\mathrm{Kn}$ showed fluctuations across months and between the sexes. The highest value was recorded during September (1.23) for male and March (1.53) for female. Both sexes had minimum Kn value during August (0.87 and 0.93 for male and female respectively. Monthly trend in $\mathrm{Kn}$ indicated spawning peaks in March 2017 and September 2017. The differences in the condition factor noticed in different months may be attributed to variations in environmental condition, food availability and gonad maturity (Jhingran, 1952; Shafi and Quddus, 1974). The 'condition' or well-being of fish determined by $\mathrm{Kn}$-factor is based on the hypothesis that heavier fish for a given length is in better condition (Bagenal and Tesch, 1978).

\section{Stomach condition}

Monthly variation in the stomach conditions of E. jonesi is shown in Tables 2 and 3. Vigorous feeding in male fishes was observed during September, July, October and December as maximum percentage of gorged (46,
$45.5,12.5$ and $24.2 \%)$ and full stomachs (47.6, 27.3, 50 and $39.4 \%$ ) were encountered during these months. Higher incidences of empty stomachs were found during April $(42.9 \%)$ and November (58.33\%). In females, occurrence of 3/4 full, full and gorged stomachs was prevalent in all months except during April 2017 (37.5\% empty stomachs) and April 2018 (50\% empty stomachs). Poor feeding activity was observed particularly during March to July, probably coinciding with the spawning season. Fully developed gonads resulted in highest $\mathrm{Kn}$ value and fishes seem to be ingesting minimum food during spawning period (Gulati, 1987). Jayabalan and Ramamoorthi (1985) also reported higher numbers of gorged and full stomachs in Gazza minuta from Porto Novo waters during September-January. The results of the present study show dissimilarity with earlier observations on the diet of the co-existing Photopectoralis bindus from Visakhapatnam waters (Rao et al., 2015); which is probably a way to avoid overlap in the ecological niche.

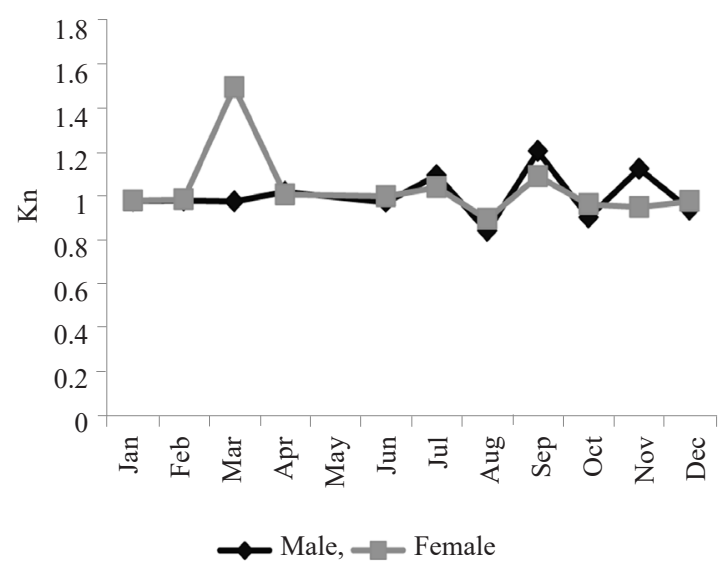

Fig. 2. Monthly relative condition factor $(\mathrm{Kn})$ of male and female $E$. jonesi in Mandapam waters during JanuaryDecember 2017

Stomach condition of male in relation to length (Fig. 3) showed that relatively higher feeding condition was seen in larger size groups of 91-100 $\mathrm{mm}$ and 
Table 2. Month-wise \% occurrence of different stomach conditions of male E. jonesi during December 2016 - April 2018

\begin{tabular}{|c|c|c|c|c|c|c|c|}
\hline \multirow{2}{*}{ Months } & \multicolumn{6}{|c|}{ Degree of fullness } & \multirow{2}{*}{ Sample size } \\
\hline & Empty & $1 / 4$ full & $1 / 2$ full & $3 / 4$ full & Full & Gorged & \\
\hline Dec 16 & 8.3 & 0.0 & 58.3 & 16.7 & 16.7 & 0.0 & 12 \\
\hline Jan 17 & 0.0 & 11.1 & 11.1 & 33.3 & 44.4 & 11.1 & 9 \\
\hline Feb & 29.4 & 35.3 & 29.4 & 0.0 & 5.9 & 0.0 & 17 \\
\hline Mar & 29.4 & 52.9 & 11.8 & 0.0 & 5.9 & 0.0 & 17 \\
\hline Apr & 42.9 & 35.7 & 21.4 & 0.0 & 0.0 & 0.0 & 14 \\
\hline May & \multicolumn{6}{|c|}{ Trawl ban period from $16^{\text {th }}$ April to $14^{\text {th }}$ June-2017 } & \\
\hline Jun & 0.0 & 16.7 & 16.7 & 16.7 & 16.7 & 33.3 & 5 \\
\hline Jul & 0.0 & 9.1 & 9.1 & 9.1 & 27.3 & 45.5 & 11 \\
\hline Aug & 15.8 & 47.4 & 21.1 & 0.0 & 15.8 & 0.0 & 19 \\
\hline Sep & 0.0 & 0.0 & 0.0 & 6.3 & 47.6 & 46.0 & 63 \\
\hline Oct & 0.0 & 12.5 & 0.0 & 25.0 & 50.0 & 12.5 & 7 \\
\hline Nov & 58.3 & 25.0 & 0.0 & 8.3 & 8.3 & 0.0 & 12 \\
\hline Dec 17 & 0.0 & 6.1 & 9.1 & 21.2 & 39.4 & 24.2 & 33 \\
\hline Jan 18 & 19.0 & 52.4 & 19.0 & 0.0 & 9.5 & 0.0 & 21 \\
\hline Feb & 0.0 & 53.8 & 7.7 & 23.1 & 15.4 & 0.0 & 13 \\
\hline Mar & 11.1 & 66.7 & 22.2 & 0.0 & 0.0 & 0.0 & 9 \\
\hline Apr & 28.6 & 42.9 & 14.3 & 14.3 & 0 & 0 & 7 \\
\hline May 18 & \multicolumn{6}{|c|}{ Trawl ban period from $15^{\text {th }}$ April to $15^{\text {th }}$ June 2018} & \\
\hline
\end{tabular}

Table 3. Month-wise \% occurrence of different stomach conditions of female E. jonesi during December 2016 - April 2018

\begin{tabular}{|c|c|c|c|c|c|c|c|}
\hline \multirow{2}{*}{ Months } & \multicolumn{6}{|c|}{ Degree of fullness } & \multirow[t]{2}{*}{ Sample size } \\
\hline & Empty & $1 / 4$ full & $1 / 2$ full & $3 / 4$ full & Full & Gorged & \\
\hline Dec16 & 2.6 & 10.3 & 12.8 & 33.3 & 23.1 & 17.9 & 39 \\
\hline Jan 17 & 0.0 & 2.8 & 8.3 & 5.6 & 19.4 & 63.9 & 36 \\
\hline Feb & 0.0 & 4.3 & 8.7 & 26.1 & 43.5 & 17.4 & 23 \\
\hline Mar & 17.4 & 13.0 & 13.0 & 30.4 & 21.7 & 4.3 & 23 \\
\hline Apr & 37.5 & 25.0 & 28.1 & 3.1 & 6.3 & 0.0 & 32 \\
\hline May & \multicolumn{6}{|c|}{ Trawl ban period from $16^{\text {th }}$ April to $14^{\text {th }}$ June-2017 } & \\
\hline Jun & 2.7 & 0.0 & 0.0 & 13.5 & 13.5 & 70.3 & 37 \\
\hline Jul & 5.3 & 5.3 & 5.3 & 26.3 & 0.0 & 57.9 & 19 \\
\hline Aug & 0.0 & 3.8 & 11.5 & 53.8 & 19.2 & 11.5 & 26 \\
\hline Sep & 0.0 & 4.9 & 9.8 & 6.6 & 42.6 & 36.1 & 61 \\
\hline Oct & 0.0 & 5.4 & 5.4 & 29.7 & 40.5 & 18.9 & 37 \\
\hline Nov & 0.0 & 21.4 & 33.3 & 28.6 & 16.7 & 0.0 & 42 \\
\hline Dec17 & 0.0 & 0.0 & 0.0 & 5.9 & 44.1 & 50.0 & 34 \\
\hline Jan 18 & 0.0 & 20.0 & 20.0 & 30.0 & 16.7 & 13.3 & 30 \\
\hline Feb & 2.8 & 36.1 & 30.6 & 5.6 & 25.0 & 0.0 & 36 \\
\hline Mar & 5.9 & 47.1 & 39.2 & 7.8 & 0.0 & 0.0 & 51 \\
\hline Apr & 50.0 & 25.0 & 14.3 & 7.1 & 3.6 & 0.0 & 28 \\
\hline May 18 & \multicolumn{6}{|c|}{ Trawl ban period from $15^{\text {th }}$ April to $15^{\text {th }}$ June 2018} & \\
\hline
\end{tabular}

101-110 mm. Empty stomachs were observed to be present in all the length groups except 71-80 $\mathrm{mm}$. In females, higher numbers of gorged and full stomachs were found in the length classes from $81-90$ to $121-130 \mathrm{~mm}$ (Fig. 4). Similar incidence of full stomachs in the length classes 101-110 and 111-120 mm was also reported by Nagarajan (2014) in female L. dussumieri off Tuticorin.

\section{Feeding intensity}

Male fishes with actively fed stomachs were prevalent during September (93.7\%), July (72.7\%) and December (63.6\%) 2017 (Fig. 5). Moderately fed fish were observed in higher percentages (75\%) during December 2016. Higher percentage of poorly fed fishes was recorded 


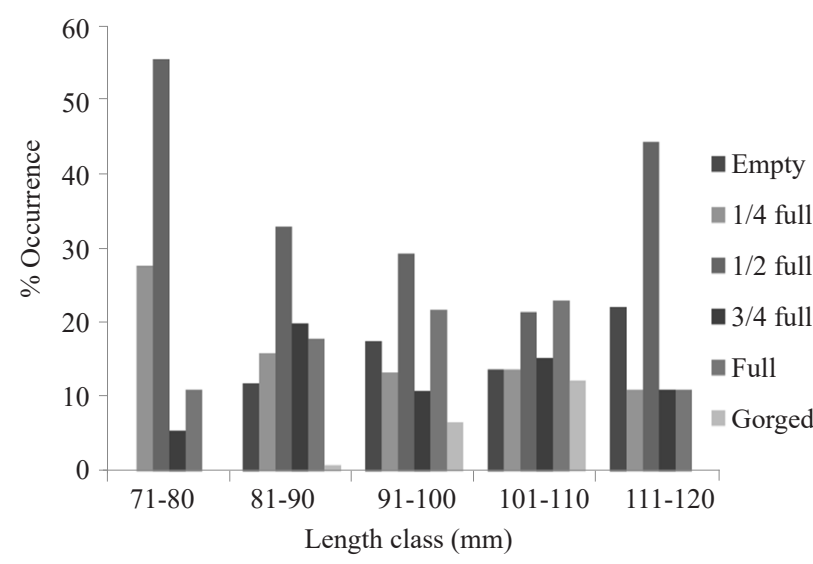

Fig. 3. Length-wise $\%$ occurrence of different types of stomach fullness of male E. jonesi during December 2016-April 2018

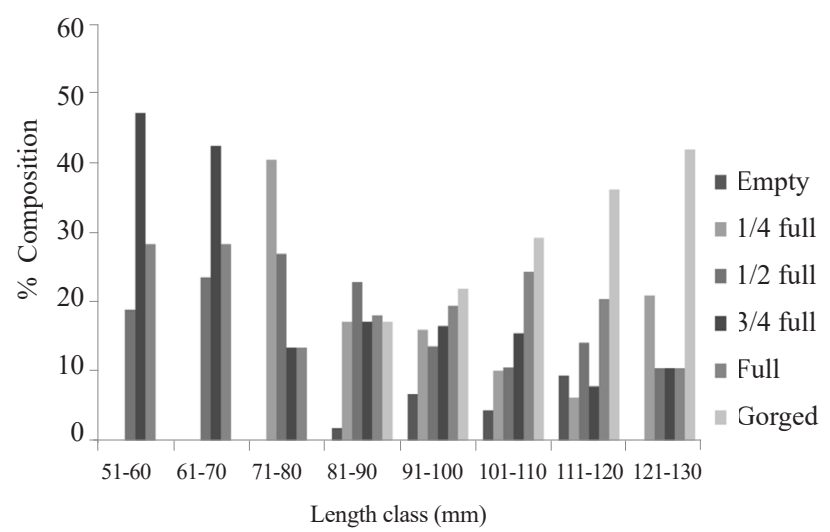

Fig. 4. Length-wise $\%$ occurrence of different stomach fullness conditions of female E. jonesi during December 2016-April 2018

during March, April, October and November. Female fishes displayed more actively fed stomachs during January (83.3\%), June (83.8\%), September (78.7\%) and December (94.1\%) (Fig. 6). Moderately and poorly fed female fishes were maximum in August (65.4\%) and April (75\%) respectively.

The percentage of feeding intensity of male and female fishes in relation to various length groups is presented in Figs. 7 and 8 respectively. Fishes with actively fed stomachs were minimum in the smallest length group of 71-80 mm for both male $(11.5 \%)$ and female $(14.3 \%)$. Thereafter it slowly increased to $35.4 \%$ in the size group $101-110 \mathrm{~mm}$ in males and $60 \%$ in the size group 111-120 mm in females. These results indicated that the feeding intensity of $E$. jones $i$ varied with season and size, with the larger size groups being in relatively better fed states than the younger size groups. As the fish grow, the size of the mouth increases proportionately, their swimming capacity is modified and their energy requirements may also vary (Qasim, 1971).

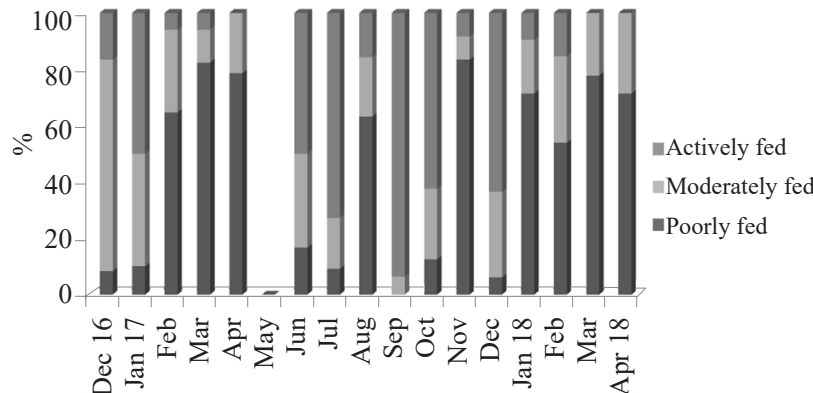

Fig. 5. Monthly feeding intensity of male E. jonesi during December 2016-April 2018

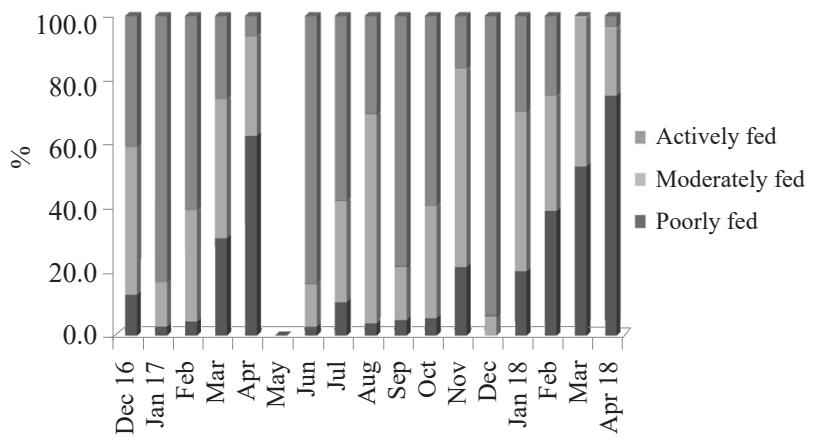

Fig. 6. Monthly feeding intensity of female E. jonesi during December 2016-April 2018

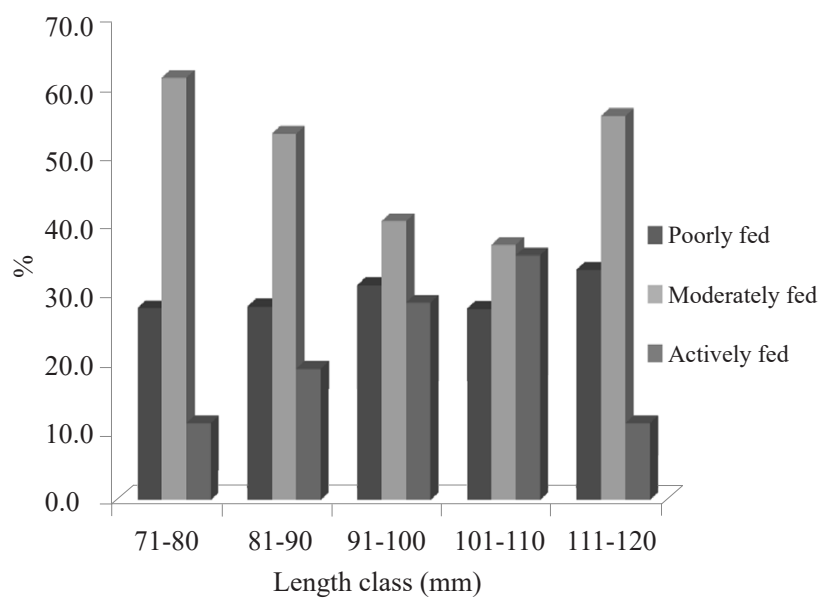

Fig. 7. Length-wise feeding intensity of male E. jonesi during December 2016 - April 2018

The monthly mean FI, GSI and Kn were highest $(2.25,2.9$ and 1.23 respectively) with lowest VI $(0 \%)$ during September 2017 for male fishes (Fig. 9). Contrarily, feeding activity almost stopped and hence highest VI $(58.33 \%)$ was observed during November. A higher percentage VI (29.41\%) and minimum FI was observed during February (0.95) and March (0.79). In the case of 


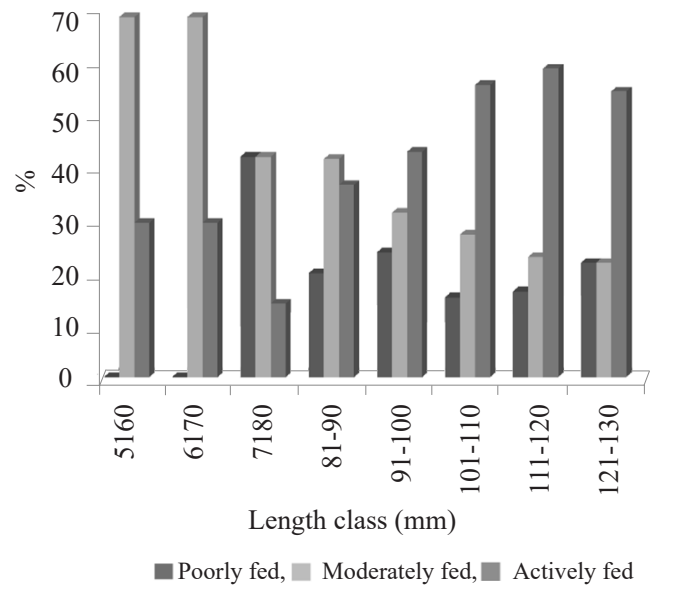

Fig. 8. Length-wise feeding intensity of female $E$. jonesi during December 2016-April 2018

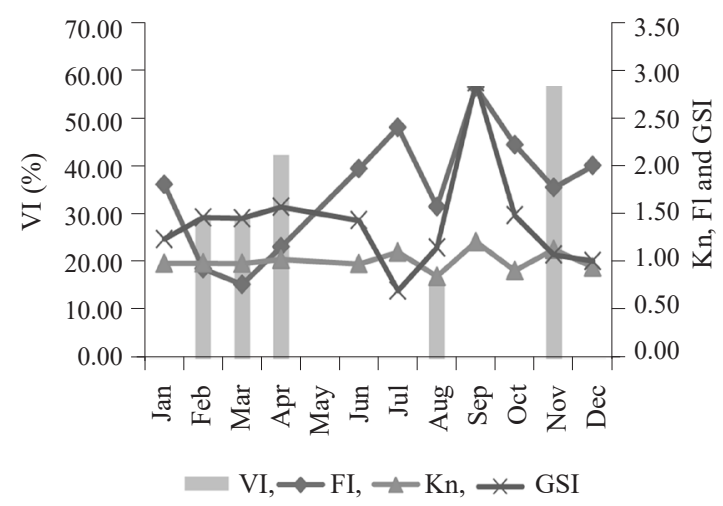

Fig. 9. Monthly variation of the FI, VI, GSI and Kn factor of male E. jonesi during 2017

female fishes (Fig. 10), maximum Kn value (1.53) and a higher GSI (3.04) was recorded during March. This was followed by the highest GSI (3.73) and VI (37.5\%) with lowest FI value (0.79) during April. The highest GSI, VI and Kn values during March and April indicated a spawning peak and hence meagre feeding, which resulted in lowest FI (unpublished data).

The feeding intensity also changed according to size of the fish. Vacouity Index was nil up to length class $61-70 \mathrm{mmin}$ male and up to $71-80 \mathrm{~mm}$ in female fishes (Fig. 11 and 12). Thereafter the mean VI became $12 \%$ in male and $2.02 \%$ in female and reached the highest values (22.22\% in male and $10 \%$ in female) at $111-120 \mathrm{~mm}$ size. Thereafter the VI again became zero. On the contrary, both sexes had the highest FI value ( 3 in male and 4 in female) in the smallest size classes, followed by a gradual decline to 1 in male at the largest size $(121-130 \mathrm{~mm})$ and 1.8 in female at $111-120 \mathrm{~mm}$. The FI of female again increased to 2.26 as it grew to the largest size of $121-130 \mathrm{~mm}$. The Kn value remained between 1.00 and 1.01 for both sexes

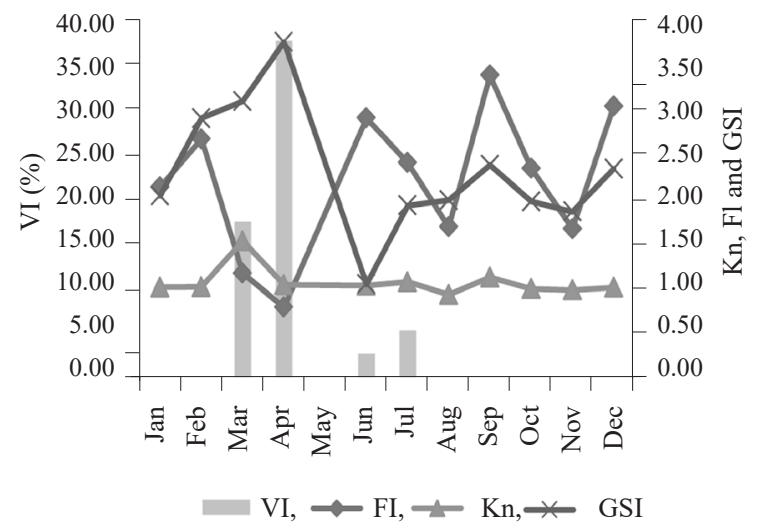

Fig. 10. Monthly variation of FI, VI, GSI and Kn of female $E$. jonesi during 2017.

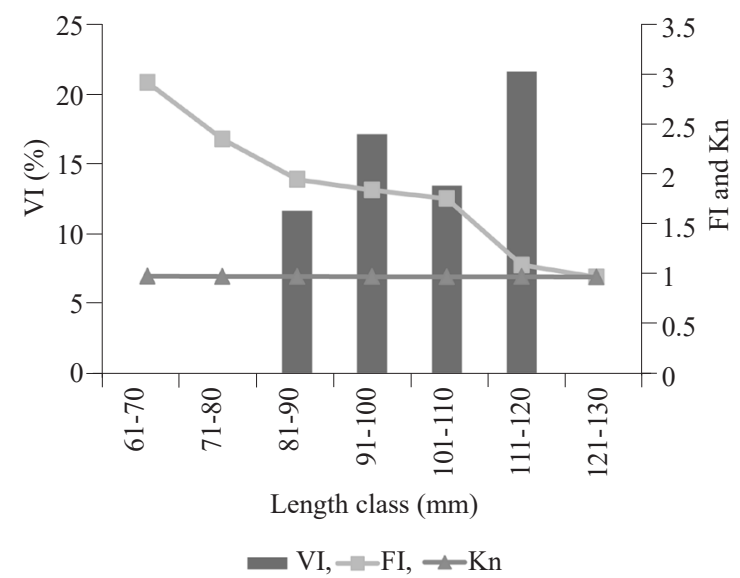

Fig. 11. Size-wise variation of the FI, VI and Kn factor of male E. jonesi during 2017

in all length class. Even though scanty details are available in literature, the present work tried to bring a combination of different indices for describing feeding biology of E. jonesi and can be considered as a first of its kind. The seasonal patterns in this study were consistent with observations by Valinassab et al. (2011) on Pomadasys kaakan and Ouakka et al. (2017) on S. pilchardus for increase in VI simultaneous with the spawning season.

\section{Diet analysis}

The gut contents of E.jonesi across different sampling months were analysed with the IRI of different food items as shown in Table 4. There was no significant difference in the feed choice of both sexes. Crustaceans dominated the food (27.6\%) except during April and November. This was followed by bivalves (23.6\%), foraminifera (15.4\%), phytoplankton $(12.5 \%)$, gastropods $(9.1 \%)$, nematodes $(8.3 \%)$ and semi-digested matter $(1.3 \%)$. Even though the content was little, Kinorhyncha and fish scales each with $0.2 \%$ were present in certain months. In April, 


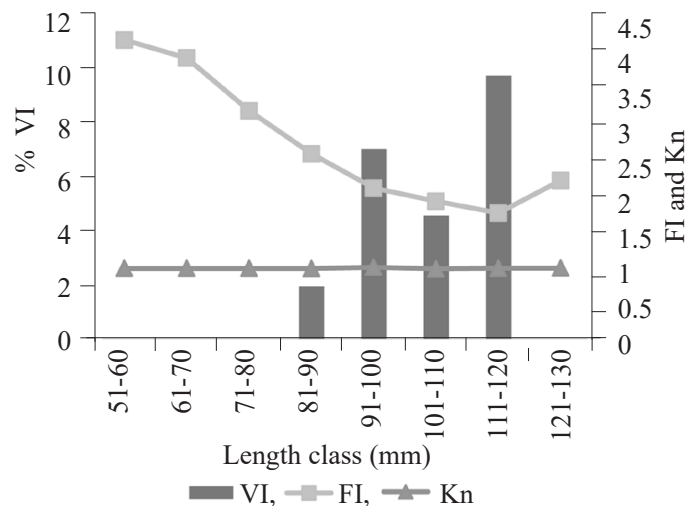

Fig. 12. Size-wise variation of FI, VI and $\mathrm{Kn}$ of female E. jonesi during 2017.

crustaceans were displaced by foraminifera and bivalves, whereas in November, phytoplankton (42.8\%), bivalves, gastropods and scales outnumbered crustaceans. Bivalves were significantly high in December and April 2017, fairly so in March 2017, December 2016 and November 2017. Nematodes were found in good quantities in September (22.3\%), August (21.2\%) and June (20.1\%). Gastropods were abundant in November 2017 and relatively high during February to April 2018. Foraminifera appeared as chief food during January (34.4\%) and April 2017 (34\%). Eggs were also present as diet in the gut from April to August 2017 (9.3-4\%) with a peak in July (12.7\%).

Percentage composition of different phytoplankton is presented in Fig. 13. Various species of phytoplankton encountered in the diet were Gyrosigma attenuatum (28\%), G. acuminatum (12\%) Coscinodiscus jonesianus (29\%), Triceratium sp. (12\%), Rhizosolenia styliformis (9\%), Nitzschia closterium (7\%), Bacteriastrum curvatum (2\%) and Cylindrotheca closterium (1\%). Percentage composition of different crustaceans in the guts of

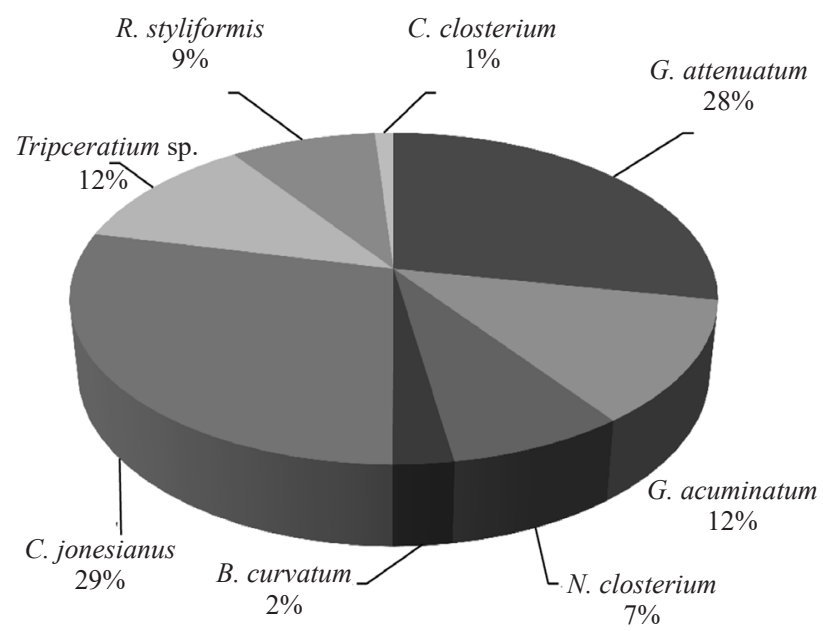

Fig. 13. Percentage composition of different phytoplankton in the guts of E. jonesi during December 2016-April 2018.

E. jonesi is shown in Fig. 14. Ostracods (42.5\%) formed the principal food item followed by harpacticoids $(25 \%)$, amphipods $(16 \%)$, calanoids $(10 \%)$, cyclopoids $(5 \%)$, cumaceans $(1 \%)$ and mysids $(0.5 \%)$.

Results of the present study indicate that E. jonesi is a planktivorous fish feeding mainly on planktonic crustaceans and phytoplankton followed by micro invertebrates and miscellaneous items. Ostracods were found to be dominant among crustaceans followed by harpacticoids and amphipods. Among phytoplankton Gyrosigma and Coscinodiscus together contributed more than $60 \%$. No significant change was noticed in diet composition with increase in size of the fish. The downward protruding mouths with slender and minute teeth on jaws enable this fish to eat zooplankton and invertebrates associated with the sea bottom. Diurnal vertical migration exhibited by $E$. jonesi results in the

Table 4. IRI of E. jonesi during December 2016-April 2018.

\begin{tabular}{|c|c|c|c|c|c|c|c|c|c|c|c|c|c|c|c|c|c|c|}
\hline \multirow{2}{*}{ Food items } & \multicolumn{18}{|c|}{ Months } \\
\hline & $\begin{array}{l}16- \\
\text { Dec }\end{array}$ & $\begin{array}{l}17- \\
\text { Jan }\end{array}$ & $\begin{array}{l}17- \\
\text { Feb }\end{array}$ & $\begin{array}{l}\text { 17- } \\
\text { Mar }\end{array}$ & $\begin{array}{l}17- \\
\text { Apr }\end{array}$ & $\begin{array}{l}17- \\
\text { May }\end{array}$ & $\begin{array}{l}17- \\
\text { Jun }\end{array}$ & $\begin{array}{l}\text { 17- } \\
\text { Jul }\end{array}$ & $\begin{array}{l}17- \\
\text { Aug }\end{array}$ & $\begin{array}{l}17- \\
\text { Sep }\end{array}$ & $\begin{array}{l}17- \\
\text { Oct }\end{array}$ & $\begin{array}{l}17- \\
\text { Nov }\end{array}$ & $\begin{array}{l}17- \\
\text { Dec }\end{array}$ & $\begin{array}{l}18- \\
\text { Jan }\end{array}$ & $\begin{array}{l}18- \\
\text { Feb }\end{array}$ & $\begin{array}{l}\text { 18- } \\
\text { Mar }\end{array}$ & $\begin{array}{l}18- \\
\text { Apr }\end{array}$ & $\begin{array}{l}18- \\
\text { May }\end{array}$ \\
\hline Phytoplankton & 6.7 & 0 & 6.6 & 23.3 & 2.5 & \multirow{10}{*}{ 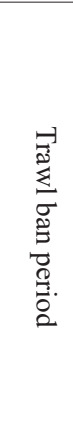 } & 17.5 & 13.6 & 17.7 & 27.8 & 15.1 & 42.8 & 12.1 & 1.7 & 2.1 & 5.2 & 0.5 & \multirow{10}{*}{ 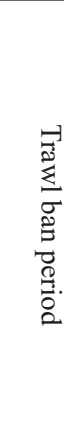 } \\
\hline Foramnifera & 24.1 & 29.4 & 10 & 15 & 27.8 & & 13.4 & 10.8 & 3.7 & 0 & 0 & 0 & 5.4 & 34.4 & 12.3 & 21.1 & 34 & \\
\hline Kinorhyncha & 0 & 0.1 & 2.4 & 0.1 & 0 & & 0.2 & 0 & 0 & 0 & 0 & 0 & 0 & 0 & 0 & 0.2 & 0 & \\
\hline Crustaceans & 25.7 & 48.1 & 42.2 & 20.9 & 0.5 & & 17.7 & 23.2 & 30.8 & 38.3 & 68.1 & 1.1 & 18 & 24.5 & 40.5 & 17.6 & 15.1 & \\
\hline Nematods & 0 & 1 & 8.2 & 2.6 & 0 & & 20.1 & 13.1 & 21.2 & 22.3 & 14.9 & 0.1 & 0 & 5.5 & 12.1 & 9.3 & 0.1 & \\
\hline Bivalves & 35.3 & 21.1 & 29.6 & 37.8 & 38.8 & & 21.9 & 16.6 & 10.3 & 6.1 & 0 & 31.4 & 44.5 & 13.3 & 14.5 & 20.1 & 28 & \\
\hline Gastropods & 4.9 & 0 & 0.7 & 0 & 13.5 & & 5.8 & 9.8 & 7.4 & 4 & 1.9 & 24.3 & 6.1 & 1.2 & 18.1 & 24.1 & 21.2 & \\
\hline Fish scale & 0 & 0 & & & & & 0 & 0 & & & & 3.2 & & 0 & & 0.2 & 0.2 & \\
\hline Eggs & 0.2 & 0 & 0.2 & 0 & 9.3 & & 0 & 12.7 & 4 & 0 & 0 & 0.2 & 0 & 0 & 0 & 0.8 & 0.8 & \\
\hline $\begin{array}{l}\text { Semi - digested } \\
\text { matter }\end{array}$ & 3.1 & 0 & 0.1 & 0 & 1.7 & & 0 & 0.3 & 2.1 & 1.5 & 0 & 0 & 9.4 & 0 & 0.2 & 1.2 & 0 & \\
\hline
\end{tabular}




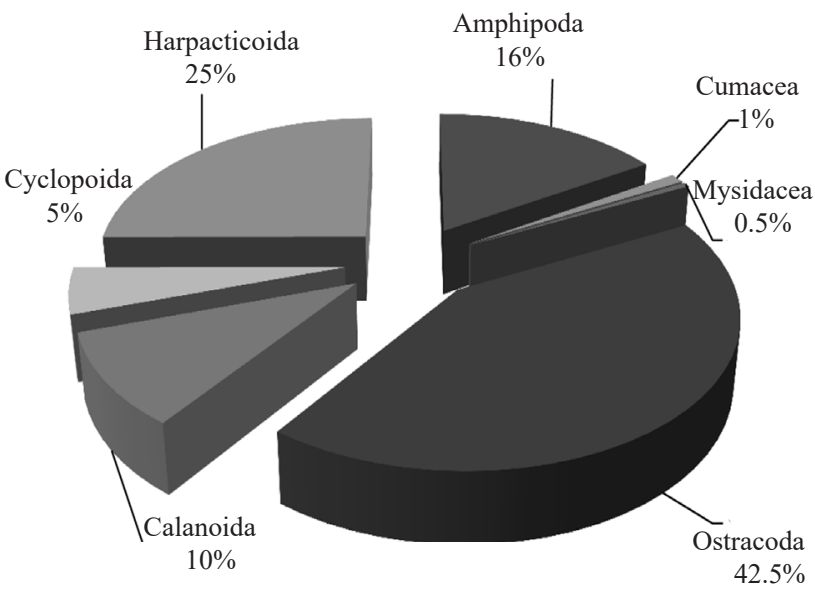

Fig. 14. Percentage composition of different crustaceans in the guts of $E$. jonesi during December 2016-April 2018

ingestion of phytoplankton during its night stay in the pelagic realm (Venkataraman and Badrudeen,1974). James and Badrudeen (1975) also identified similar food items in the guts of $L$. bevirostris inhabiting Palk Bay. James (1986), based on his observation on diet composition of $E$. jonesi from Mandapam opined that the species prefers planktonic organisms.

\section{Acknowledgements}

The authors are grateful to Dr. A. Gopalakrishnan, Director, ICAR-CMFRI, Kochi for the encouragement and facilities provided. The authors also wish to express sincere thanks to Shri. A. Gandhi and U. Rajendran, Technical staff, Mandapam RC of ICAR-CMFRI; Shri. R. Arogiyam, boat owner; R. Prasanna and Muthu Meeran Marakkayar, fishermen for extending help during sample collection.

\section{References}

Acharya, K. V. and Naik, S. D. 2016. Food and feeding habit of pony fish, Leiognathus splendens (Cuvier, 1829) off Ratnagiri coast, Maharashtra. IJSER, 7(9): 122-133.

Bagenal, T. B. and Tesch, F. W. 1978. Age and growth. In: Bagenal, T. B. (Ed.), Methods for the assessment of fish production in freshwaters. Blackwell Scientific Publication, Oxford, UK, p. 101-136.

Balan, V. 1967. Biology of the silverbelly, Leiognathus bindus (Val.) of the Calicut coast. Indian J. Fish., 10: 118-134.

Batcha, H. and Badrudeen, M. 1992. Length-weight relationship and relative condition of Leiognathus brevirostris (Valenciennes) from the Palk Bay. J. Mar. Biol. Ass. India, 34 (1 \& 2): 269-270.

Borah, B. S., Nirmale, V. H., Metar, S. Y., Bhosale, B. P., Chogale, N. D. and Pawar, R. A. 2016. Biology of silverbelly, Photopectoralis bindus (Val. 1835) along Ratnagiri Coast. Fish Technol., 53: 89-95.
CMFRI 2018. Annual Report 2017-18. ICAR-Central Marine Fisheries Research Institute, Kochi, India, p. 33-90.

Gulati, D. K. 1987. Morphometry, biology and stock assessment of Otolithes cuvieri (Trewavas) off the Bombay coast. M. Sc. Thesis, Bombay University, India, 185 pp.

Hynes, H. B. N. 1950. The food of freshwater sticklebacks (Gasterosteus aculeatus and Pygosteus pungitius) with a review of methods used in studies of the food of fishes. J. Anim. Ecol., 19: 36-58. DOI: 10.2307/1570.

Hyslop, E. J. 1980. Stomach contents analysis - a review of methods and their application. J. Fish Biol., 17: 411-429. doi.org/10.1111/j.1095-8649.1980.tb02775.x.

James, P. S. B. R. and Badrudeen, M. 1975. Biology and fishery of Leiognathus brevirostris (Val.) from the Palk Bay and the Gulf of Mannar. Indian J. Mar. Sci., 4: 50-59.

James, P. S. B. R. and Badrudeen, M. 1981. Biology and fishery of silverbelly Leiognathus dussumieri (Val.) from Gulf of Mannar. Indian J. Fish., 28 (1 \& 2): 154-182.

James, P. S. B. R. 1986. Biology and fishery of Leiognathus jonesi James from the Palk Bay and Gulf of Mannar. In: Recent advances in marine biology. Today and Tomorrow Printers and Publishers, New Delhi, India, p. 29-101.

Jayabalan, N. and Ramamoorthi, K. 1985. Food and feeding habits of the silverbelly, Gazza minuta (Bloch) in Porto Novo waters. Indian J. Mar. Sci., 14: 110-112.

Jhingran, V. J. 1952. Length-weight relationship of three major carps in India. Proc. Nat. Inst. India, XVII(5): 449-460.

Jin, S., Yan, X., Zhang, H. and Fan, W. 2015. Weight-length relationships and Fulton's condition factors of skipjack tuna (Katsuwonus pelamis) in the western and central Pacific Ocean. Peer J., 1-11.

Karthikeyan, M., Pillai, N. G. K. and Badrudeen, M. 1989. Population dynamics of silverbelly, Leiognathus jonesi, James in the trawling grounds of Rameswaram, Indian $J$. Fish., 36(2): 103-106.

Kizhakudan, S. J. and Reddy, P. S. 2012. Length-weight relationship in three species of silverbellies from Chennai coast. Indian J. Fish., 59(3): 65-68.

Le Cren, C. D. 1951. Length-weight relationship and seasonal cycle in gonad weights and condition in the perch (Perca fluviatilis). J. Anim. Ecol., 20: 201-219.

Nagarajan, D. 2014. Food and feeding in Leiognathus dussumieri (Valenciennes) from Tuticorin, south-east coast of India. Trans. Eng. Sci., 2(5): 1-6.

Ouakka, K., Yahyaoui, A., Mesfioui, A. and Ayoubi, S. E. 2017. Stomach fullness index and condition factor of European sardine (Sardina pilchardus) in the south Moroccan Atlantic coast. ACCL Bioflux, 10(1): 56-63.

Pinkas, L., Olipahnt, M. S. and Iverson, I. L. K. 1971. Food habits of albacore, bluefin tuna and bonito in Californian waters. Fish. Bull., 152: 1-105. 
Preciado, J. A. R., Amezcua, F., Bellgraph, B. and Madrid, J. V. 2014. Feeding habits and trophic level of the Panama grunt Pomadasys panamensis, an important bycatch species from the shrimp trawl fishery in the Gulf of California. Sci. World J., 2014: 1-7. doi.org/10.1155/2014/864241.

Puvaneswari, S. and Karuppasamy, R. 2019. Length-weight relationship of the toothed pony fish, Gazza minuta (Bloch, 1797) from Tuticorin waters of India. IJSRBS, 6(3): 119-123. doi.org/10.26438/ijsrbs/v6i3.119123.

Qasim, S. Z. 1971. Dynamics of food and feeding habits of some marine fishes. Indian J. Fish., 19 (1 and 2): 12-28.

Rao, P. Y., Veni, D. N. K. and Sirisha, R. 2015. Biology of orange fin pony fish, Photopectoralis bindus (Valenciennes, 1835), off Visakhapatnam, east coast of India. Int. J. Environ. Sci., 5(6): 1159-1171.

Sebastian, H. and Inasu, N. D. 2011. Observations on the diet of the silverbelly Leiognathus brevirostris (Valenciennes 1835) from Kerala coast. J. Mar. Biol. Ass. India, 53(2): 202-207.
Shafi, M. and Quddus, M. M. 1974. Length-weight relationship and condition factor in Hilsa ilisha (Hamilton) (Clupeiformes: Clupeidae). Bangladesh J. Zool., 2(2): 179-185.

Snedecor, G. W. and Cochran, W. G. 1967. Statistical methods. Oxford and IBH Publishing Co., New Delhi, 593 pp.

Strum, L. M. G. 1978. Aspects of the biology of Scombemorus maculates (Mitchill) in Trinidad. J. Fish Biol., 13: 155-172.

Valinassab, T., Jalali, S., Hafezieh, M. and Zarshenas, G. A. 2011. Evaluation of some feeding indices of Pomadasys kaakan in the Northern Persian Gulf. Iran. J. Fish. Sci., 10(3): 497-504.

Venkataraman, G. and Badrudeen, M. 1974. On the diurnal variation in the catches of silverbellies in the Palk Bay. Indian J. Fish., 2(1): 254-265

von Bertalanffy, L. 1938. A quantitative theory of organic growth. Hum. Biol., 10: 181-213. 